Cadernos de Literatura em Tradução, n. 5, p.27-42

\title{
Três poemas de Kipling
}

Gil Pinheiro

Ezra Pound dizia que o bom poema sobrevive às paródias que se fazem dele. Poema algum, talvez, ao longo do século XX, terá sido tão parodiado quanto If, de Rudyard Kipling. Como a corroborar a tese de Pound, o poema foi eleito, em 1995, o meIhor de todos os tempos em uma enquete popular na Inglaterra. A trajetória do criador confunde-se com a da criatura. Durante muito tempo, Kipling permaneceu na mira dos críticos, sob a acusação de chauvinismo, racismo e imperialismo. Hoje, parece, começa-se a suspeitar de que, na verdade, os ideais de legalismo, promoção de todas as raças a uma única humanidade e responsabilidade do colonizador para com o colonizado traduzem meIhor o ideário do poeta. Seja como for, ofereço aqui uma nova tradução de If, esperando contemplar o que identifico no original como um "estoicismo instrumental" - isto é, muito mais o receituário de um homem de ação do que propriamente a defesa da indiferença e da superioridade às paixões que, afinal, tem sido o chamariz de tanta paródia mal-sucedida.

Os outros dois poemas - The Story of Uriah e The Betrothed -, pertencem ambos à primeira fase do autor. Tem-se repetido muito, por influência de um famoso ensaio de Eliot' ${ }^{\prime}$, que Kipling é um grande versejador mas só eventualmente um poeta. Há, hoje, quem prefira lançar mão desse mote para caracterizar apenas 
PINHEIRO, Gil. Três poemas de Kipling.

seus primeiros versos, e não sua obra como um todo. Minhas traduções encerram a pretensão de também isso questionar. A conclusão de Eliot é o corolário de uma tese segundo a qual Kipling "não procura pela forma, mas somente pela forma específica de cada poema", usando a poesia como "mero instrumento" do que poderia comunicar, por exemplo, em contos. Não é o que se observa na prática ao traduzir esses versos. $\bigcirc$ esforço logopéico que exigem do tradutor não deixa dúvidas quanto à presença de um fazer eminentemente poético.

\section{$\mathrm{SE}^{2}$}

SE não perdes a cabeça e o tempo é tal

Que a loucura inflama todos contra ti;

Ou, caindo no descrédito geral,

Sem melindres continuas crendo em ti;

Se consegues sem desânimo esperar,

Sem rancores com rancores rebater

Nem mentiras com mentiras rechaçar,

Sem com isso sábio ou santo querer ser;

Se liberto da ilusão podes sonhar

E pensar sem chafurdar no pensamento;

Se ao sucesso e ao insucesso sabes dar

Sempre o mesmo indiferente tratamento;

Se consegues suportar que tuas idéias

Virem lábia de patifes contra os tolos;

Ou se a queda de tua obra mal pranteias

E começas a reerguer os teus tijolos; 
Se consegues apostar tudo que tens,

Em uma única cartada, e então perder, Sem jamais chorar à míngua de teus bens

Nem diante o recomeço esmorecer;

Se consegues coração, nervos e músculos

Empenhar além da força que te assiste, Até nada mais restar senão, minúsculos,

Os apelos da vontade, que persiste;

Se não perdes entre a plebe a distinção

E, entre reis, um certo quê de popular;

Se consegues dar as mãos - co's pés no chão-

E inimigos - ou amigos - enfrentar;

$\mathrm{Se}$, segundo por segundo, os teus minutos

Dão à volta do ponteiro honesto trilho,

Tua é a terra inteira e todos os seus frutos

$E$, acima de tudo, és um homem, meu filho.

\section{O CONTO DE URIAS}

"Havia em uma cidade dois

homens; um rico e outro pobre." ${ }^{3}$

JACK BARRETT foi a Qüetta ${ }^{4}$

A rufo de tambor.

Com três partes do soldo

Em Shimla ${ }^{5}$ deixou Lenore ${ }^{6}$.

Tombou tão pronto em Qüetta, 
PINHEIRO, Gil. Três poemas de Kipling.

Que nem viu de outubro a cor.

Jack Barrett foi a Qüetta,

Sem justa explicação,

Estranha transferência

No mais belo da estação.

Partiu era setembro,

E morreu de supetão.

Jack Barrett foi a Qüetta,

E lá se despediu,

Lutando por dois homens

No "bom posto" que assumiu.

Lenore vestiu-lhe luto,

Mas penúria nunca viu.

Jack Barrett hoje em Qüetta

Inânime se espraia,

Mas quem apostaria

Que em espírito não saia

A perguntar por que

O arrancaram do Himalaia?

E quando o Toque do Clarim

Ecoe sobre o Harnai ${ }^{7}$,

E o Livro Negro da Chacota

Enfim revele o guai,

Se a cova que devora a carne

O espírito propele,

De quem mandou Jack Barrett lá

Eu não desejo a pele. 


\section{COMPROMETIDO}

"Você terá de escolher: ou seus charutos ou eu." 8

ABRA a velha charuteira, dê-me um Havana encorpado, Que meu noivado com Maggie está ficando complicado.

A causa da desavença reside no meu charuto.

Acuso-a de intransigência, diz ela que eu sou um bruto.

Abra a velha charuteira, que eu quero ficar entregue Aos auspícios da fumaça, lembrando a face de Maggie.

Maggie é bonita de ver - promessa de amor certeira - , Mas beleza acaba em ruga, e amor não dura a vida inteira.

Tão pacato é um Laranaga, pacífico um Henry Clay?, E o melhor dos bons charutos em uma hora já fumei.

Fumei e troquei por outro - novinho, enxuto, perfeito -, Já trocar Maggie por outra não será tão bem aceito.

Que tal Maggie em seus cinqüenta - grisalha, ranzinza e velha -,

Sem Maggie sobressalente que restitua a centelha?

Nem que o fogo do passado se torne a luz do presente, Quando o amor recenda a sarro como cinza remanente, 
PINHEIRO, Gil. Três poemas de Kipling.

A ponta de um bom charuto - mas morto no bolso pode

Concorrer com fumo novo, que ao pigarro nos acode.

Abra a velha charuteira - que o momento é de escolher: Aqui um suave Manilla ${ }^{10}$; lá um sorriso de mulher.

Qual será o melhor partido: servidão selada a anel Ou um harém de folhas finas ofertadas a granel?

Cinqüenta noivas por caixa - conforto sincero e certo -, Nenhuma delas bicuda com tanta rival por perto.

Meditação matutina; consolo em tempo de dor; Paz na calada da noite; e, à porta do sono, torpor.

Eis o dote que as cinqüenta, em sacrifício, me darão Com devoção de satis ${ }^{12}$ - incineradas na missão.

Eis o dote que as cinqüenta me darão sem compromisso $E$, mortas, outras cinqüenta já estarão a meu serviço.

As ilhas das Caraíbas, e a ilha de Java também, Cuidarão de manter sempre renovado meu harém -

Harém nutrido sem jóias nem sedas nem pão-de-ló -, Caiam raios ou gaivotas, faça chuva ou faça sol.

Só o perfume da baunilha e o tempero de um bom chá Darão charme às minhas noivas de vexar as de um paxá. 
E Meggie insiste, por carta, que eu faça a escolha mofina Entre o merencório Amor e a grande deusa Nicotina.

Faz doze minguados meses - se tanto - que sigo o amor, Mas das graças de um Partagas ${ }^{13}$ sou primígeno cultor.

Minha vida de solteiro, há sete anos ou mais, Brilha ao tabaco que acendo, quer na guerra quer na paz.

Mas se o futuro com Maggie não der ponta que acender, Nada mais que o amor ardente dará luz ao que vier.

Será luzeiro seguro? Ou morro com ele na lama? Cubro de uma baforada ou sigo as chispas desta chama?

Abra a velha charuteira - vale a pena perguntar:

Quem é Maggie que me ordena amigas velhas dispensar?

Há milhares de outras Meggies igualmente em pé de caça Mas mulher é só mulher, e um bom charuto é fumaça!

Outro Havana, por favor - que estou, bem sei, comprometido.

Se Maggie não quer rivais, serei tampouco seu marido. 
IF you can keep your head when all about you Are losing theirs and blaming it on you;

If you can trust yourself when all men doubt you, But make allowance for their doubting too;

If you can wait and not be tired by waiting, Or, being lied about, don't deal in lies, Or, being hated, don't give way to hating, And yet don't look too good, nor talk too wise;

If you can dream - and not make dreams your master; If you can think - and not make thoughts your aim;

If you can meet with triumph and disaster And treat those two imposters just the same;

If you can bear to hear the truth you've spoken Twisted by knaves to make a trap for fools, Or watch the things you gave your life to broken, And stoop and build 'em up with wornout tools;

If you can make one heap of all your winnings And risk it on one turn of pitch-and-toss, And lose, and start again at your beginnings And never breath a word about your loss; If you can force your heart and nerve and sinew To serve your turn long after they are gone, And so hold on when there is nothing in you Except the Will which says to them: "Hold on";

If you can talk with crowds and keep your virtue, Or walk with kings - nor lose the common touch; 
If neither foes nor loving friends can hurt you;

If all men count with you, but none too much;

If you can fill the unforgiving minute

With sixty seconds' worth of distance run Yours is the Earth and everything that's in it, And - which is more - you'll be a Man my son!

\section{THE STORY OF URIAH}

"Now there were two men in one city; the one rich, and the other poor."

JACK BARRETT went to Quetta

Because they told him to.

He left his wife at Simla

On three-fourths his monthly screw. Jack Barrett died at Quetta

Ere the next month's pay he drew.

Jack Barrett went to Quetta.

He didn't understand

The reason of his transfer

From the pleasant mountain-land.

The season was September,

And it killed him out of hand.

Jack Barrett went to Quetta

And there gave up the ghost, 
PINHEIRO, Gil. Três poemas de Kipling.

Attempting two men's duty In that very healthy post; And Mrs. Barrett mourned for him Five lively months at most.

Jack Barrett's bones at Quetta Enjoy profound repose;

But I shouldn't be astonished If now his spirit knows The reason of his transfer

From the Himalayan snows.

And, when the Last Great Bugle Call Adown the Hurnai throbs, And the last grim joke is entered In the big black Book of Jobs, And Quetta graveyards give again Their victims to the air, I shouldn't like to be the man Who sent Jack Barrett there.

\section{THE BETROTHED}

"You must choose between me and your cigar."

OPEN the old cigar-box, get me a Cuba stout, For things are running crossways, and Maggie and I are out. 
We quarrelled about Havanas - we fought o'er a good cheroot,

And I knew she is exacting, and she says I am a brute.

Open the old cigar-box — let me consider a space;

In the soft blue veil of the vapour musing on Maggie's face.

Maggie is pretty to look at - Maggie's a loving lass, But the prettiest cheeks must wrinkle, the truest of loves must pass.

There's peace in a Larranaga, there's calm in a Henry Clay;

But the best cigar in an hour is finished and thrown away

Thrown away for another as perfect and ripe and brown But I could not throw away Maggie for fear o' the talk o' the town!

Maggie, my wife at fifty — grey and dour and old -

With never another Maggie to purchase for love or gold!

And the light of Days that have Been the dark of the Days that Are,

And Love's torch stinking and stale, like the butt of a dead cigar -

The butt of a dead cigar you are bound to keep in your pocket -

With never a new one to light tho' it's charred and black to the socket! 
PINHEIRO, Gil. Três poemas de Kipling.

Open the old cigar-box - let me consider a while. Here is a mild Manila - there is a wifely smile.

Which is the better portion - bondage bought with a ring, Or a harem of dusky beauties, fifty tied in a string?

Counsellors cunning and silent - comforters true and tried, And never a one of the fifty to sneer at a rival bride?

Thought in the early morning, solace in time of woes, Peace in the hush of the twilight, balm ere my eyelids close,

This will the fifty give me, asking nought in return, With only a Suttee's passion — to do their duty and burn.

This will the fifty give me. When they are spent and dead, Five times other fifties shall be my servants instead.

The furrows of far-off Java, the isles of the Spanish Main, When they hear my harem is empty will send me my brides again.

I will take no heed to their raiment, nor food for their mouths withal,

So long as the gulls are nesting, so long as the showers fall.

I will scent 'em with best vanilla, with tea will I temper their hides, 
And the Moor and the Mormon shall envy who read of the tale of my brides.

For Maggie has written a letter to give me my choice between

The wee little whimpering Love and the great god Nick o' Teen.

And I have been servant of Love for barely a twelvemonth clear,

But I have been Priest of Cabanas a matter of seven year;

And the gloom of my bachelor days is flecked with the cheery light

Of stumps that I burned to Friendship and Pleasure and Work and Fight.

And I turn my eyes to the future that Maggie and I must prove,

But the only light on the marshes is the Will-o'-the-Wisp of Love.

Will it see me safe through my journey or leave me bogged in the mire?

Since a puff of tobacco can cloud it, shall I follow the fifful fire?

Open the old cigar-box - let me consider anew Old friends, and who is Maggie that I should abandon you?

A million surplus Maggies are willing to bear the yoke; 
PINHEIRO, Gil. Três poemas de Kipling.

And a woman is only a woman, but a good Cigar is a Smoke.

Light me another Cuba — I hold to my first-sworn vows. If Maggie will have no rival, I'll have no Maggie for Spouse!

\section{NOTAS}

1. Eliot, T.S., "Rudyard Kipling" em On Poetry and Poets, Faber and Faber, Londres, 1984.

2. Kipling teria escrito este poema em homenagem ao amigo Leander Starr Jameson (1853-1917), em quem identificava as qualidades exaltadas. Em 1895, Jameson, sem a permissão explícita de Cecil Rhodes - então primeiro-ministro da colônia britânica do Cabo, na África do Sul -, liderou 500 homens em um ataque contra os bôers, holandeses que colonizavam o Transvaal. Derrotado, foi julgado na Inglaterra e passou alguns meses na prisão. $\bigcirc$ que não o impediu de tornar-se herói popular em Londres nem o progresso de sua carreira política na colônia. Em 1902, com a morte de Rhodes, de quem sempre foi amigo, Jameson assumiu a liderança do Partido Progressista na África do Sul. Em 1909, recebeu o título de sir. Jameson, Rhodes e Kipling compartilhavam o ideal de uma África unida sob bandeira britânica. Graças a uma tradução de Guilherme de Almeida, If (Se...) também se tornou muito popular no Brasil. Segue, na íntegra, a versão famosa: Se és capaz de manter a tua calma quando/Todo mundo ao teu redor já a perdeu e te culpa;/ De crer em ti, quando estão todos duvidando,/ E para esses, no entanto, achares uma desculpa;/ Se és capaz de esperar sem te desesperares;/ Ou, enganado, não mentir ao mentiroso,/ Ou, sendo odiado, sempre ao ódio te esquivares,/ E não parecer bom demais nem pretensioso; Se és capaz de pensar, sem que a isso só te atires;/ De sonhar, sem fazer dos sonhos teus senhores;/ Se, encontrando a Desgraça e o Triunfo, conseguires /Tratar da mesma forma esses dois impostores;/ 
Se és capaz de sofrer a dor de ver mudadas/Em armadilhas as verdades que disseste,/ $\mathrm{E}$ as coisas por que deste a vida, estraçalhadas,/ E refazê-las com o bem pouco que te reste;/ Se és capaz de arriscar numa única parada/ Tudo quanto ganhaste em toda a tua vida,/ E perder, e ao perder, sem nunca dizer nada,/ Resignado, tornar ao ponto de partida;/ De forçar coração, nervos, músculos, tudo,/ A dar o que for que neles ainda existe;/ E a persistir assim quando exausto, contudo,/ Resta a vontade em ti que ainda ordena:"Persiste"!/ Se és capaz de, entre a plebe, não te corromperes,/ $E$, entre reis, não perder a naturalidade;/ $E$ de amigos, quer bons, quer maus, te defenderes, / Se a todos podes ser de alguma utilidade;/Se és capaz de dar, segundo por segundo,/ Ao minuto fatal todo o valor e brilho,/ Tua é a terra, com tudo o que existe no mundo,/ $\mathrm{E}$ - o que é mais - serás um Homem, meu filho!

3. Citação bíblica (Reis II 12:1). Com essas palavras o anjo Natan inicia a párabola com que censura Davi pela morte de Urias. A história, paradigma do poema, é conhecida. O rei Davi engravida Betsabá, mulher do soldado Urias, enquanto este está fora, lutando por Israel. Davi tenta várias vezes convencer o soldado a largar a batalha e ir dormir com a mulher, a fim de transferir-lhe a paternidade. Como Urias se recusa a abandonar os companheiros de luta, o rei ordena que o destaquem para um posto em que ele não possa escapar com vida. A ordem é cumprida e Urias morre. Davi, então, inclui Betsabá entre suas esposas.

4. Qüetta, hoje, é uma cidade do estado do Baluchistão, no Paquistão. Recentemente, tornou-se notícia como palco de violentos protestos da população islâmica contra os ataques americanos ao Afeganistão (outubro de 2001). O nome "Qüetta" tem origem palavra kweita, do pashtu, e significa "forte". De fato, cercada de altas montanhas, a cidade constitui uma fortificação natural. Em 1876, foi ocupada pelo exército inglês e, em 1887, anexada oficialmente à Índia sob jurisdisção britânica. Entre 1879 e 1881, desempenhou papel importante na guerra que os ingle- 
PINHEIRO, Gil. Três poemas de Kipling.

ses travaram contra os afegãos porque concentrava pontos estratégicos de acesso ao território inimigo. Na verdade, a sorte do infeliz Jack Barrett, que protagoniza o poema, parece estar ligada aos conflitos que se seguiram a essa ocupação.

5. Encravada no Himalaia, a cidade de Shimla (ou Simla) foi estação de férias e capital oficial de verão do governo britânico na Índia (1865-1939). Kipling passou várias temporadas lá na década de 80 do século 19. À época em que o poema foi escrito, a cidade era famosa pelo clima de intriga e romance. Admirada pela beleza e pela esplêndida visão que propicia dos picos nevados é, atualmente, importante centro turístico da ĺndia.

6. Kipling, no original, não dá nome à mulher de Barrett. "Lenore", portanto, é uma invenção, ou se se preferir, uma traição do tradutor por recurso de rima.

7.Região repleta de vales e montanhas em que está localizada a cidade de Qüetta.

8. Em algumas edições, a epígrafe do poema é remetida aos autos de um caso judicial de quebra de compromisso de 1885.

9, 10, 11 e 13. Laranaga, Henry Clay e Partagas são marcas tradicionais de charutos originalmente fabricados em Cuba. Manilla é o charuto proveniente das Filipinas.

12. Satis: viúvas queimadas vivas na pira mortuária de seus maridos (prática tradicional na Índia, hoje proibida por lei). 